\title{
TOP - DOWN PROCESSING IN LISTENING FOR ENGLISH FOREIGN LANGUAGE (EFL) STUDENTS
}

\author{
Dewi Nopita \\ English Education Department \\ Teacher Training and Education Faculty \\ Universitas Maritim Raja Ali Haji, Tanjungpinang, Kepulauan Riau, Indonesia \\ e-mail: dewinopita.umrah@gmail.com
}

\begin{abstract}
Possessing listening skill for English Foreign Language (EFL) students is not an easy task. Most students are struggling on sound and sentence clarity to get the meaning of the spoken messages. This article illustrates a process that can help students arrive at the meaning without totally focus on the details of sounds. The process is known as top-down processing. In the process, the students' background knowledge of the topic is much more involved. How the process looks like is illustrated through how it works in intensive, selective, and extensive listening activity.
\end{abstract}

Key words/ phrases: top - down processing, listening, English Foreign Language (EFL) students

\section{INTRODUCTION}

Listening is considered to be a complex process. In listening, listeners need both linguistic and non-linguistic knowledge. These knowledge are simultaneously integrated in the process. Linguistic knowledge - the knowledge of the language system - consists of the knowledge of phonology, stress, intonation, lexis, and syntax. Nonlinguistic knowledge, then, links to listeners' knowledge about the topic (such as situation, participants, genre, etc) (Anderson and Lynch in Nunan, 2001; White, 2008).

Besides, there are two different kinds of processes involve in understanding the meaning of a spoken message, bottom - up processing and top down processing. The first deals with a process in which listeners analyze sounds, words, clauses, sentences, and texts to derive the meaning of the message. In doing so, the listeners' lexical and grammatical competence become the basis of the process. On the other hand, top - down processing is using background knowledge in understanding the meaning of the message. This process goes from listeners' mind to text (Richards, 2008).

Based on my observation, for EFL students in which English is learned as a foreign language, listening is regarded as the most difficult skill. Seemingly, this is due to the students' unfamiliarity with English speech sounds. To the students' views, when they listen to spoken messages, they get problems with sounds and vocabulary. As a result, they look confused and ask me to repeat the passage again and again.

Dealing with the students' views, it seems that they depend much on sound, word, and sentence clarity to arrive at the meaning. As soon as they get the sounds, they consult their dictionaries to make them sure about the words. To cope with this, teachers have to gear their students up with a learning attitude that listening is not a task to look for sounds, words, and sentences but it is more about looking for 
meaning (Lingzhu, 2003). In other words, the students' views need to be changed.

Considering the complexity and the aim of listening, EFL students have to focus more on meaning when they are receiving spoken messages. In this case, the students can employ top-down processing in listening activities. Throughout this article, I would like to illustrate what the students can do in topdown processing when they are in listening activities.

\section{THE PRINCIPLE OF TOP - DOWN PROCESSING}

Regarding the pivotal role of listening skill in EFL classrooms, as one of the language skills which an EFL student has to possess, top-down processing can give much contribution. In employing this process, students refer to all background knowledge they have related to the topic of the spoken messages they are listening to. The background knowledge includes topic, life experiences, educational experiences, cultural experiences, knowledge of how the first language works as well as how the second language works, and the knowledge of how text is organized rhetorically. These knowledge functions as helping students have conceptual framework or 'script' for understanding. Consequently, the students do not need to totally focus on details of sounds, words, and sentences to get the meaning (Vandergrift, 2004; Anderson, 2008).

According to White (2008), in topdown processing, the students involve their contextual and schematic knowledge as the basis for understanding. Dealing with this, Macaro (2001) states that contextual information is about who the speakers are, where the conversation takes place, and what has already been said. These information contributes to the students' ability to make inferences about what is happening/ what the speakers are talking about and what will come next. Moreover, schematic knowledge includes discourse organization, the use of language in a particular society, and factual knowledge of the topic.

Next, Richards (2008) explains that top-down processing trains the students to do several things; use key words to construct the schema of a discourse, infer the setting for a text, infer the role of the participants and their goals, infer causes or effects, infer unstated details of a situation, anticipate questions related to the topic or situation. In addition, he also provides several activities for the students which can develop their top-down listening skill. The activities are done as soon as they get the topic of the passage (listening material). They are generating possible questions and list of things they have already known related the topic, predicting what other speaker is going to say after reading another speaker's part, reading a list of the key to be covered in talk, trying to complete a story ending after listening to part of a story, and guessing what happened after reading news headlines.

From the theories, it is obvious that students' background knowledge is truly essential in top - down processing. The background knowledge consists of contextual and schematic knowledge about the topic that the students have already had.

\section{LISTENING FOR EFL STUDENTS}

For EFL students, listening aims at understanding spoken language. In learning listening, the students are not only taught receptive skill but also productive skill. The first skill deals with when the students are listening to a spoken language and the second skill is when the students produce something. Besides, in the process of understanding a spoken message, EFL students involve all skills and knowledge they commonly employ in other language skills. It indicates that the skills and the knowledge used in listening is closely related to those of speaking, reading, and writing (Saricoban, 1999; Rost, 2009). 
Brown (2004) divides listening task into four basic types - intensive, responsive, selective, and extensive. Intensive listening is giving a longer stretch of language to the students in order to give them the perception of its components (phonemes, words, intonation, discourse markers, etc). The second task is to train students to give response to a relatively short stretch of language ( $\mathrm{a}$ greeting, question, command, comprehension check, etc). Then, selective listening is a task which provide students with a designated information in a context of longer stretches of spoken language to see whether the students can comprehend it or not. Next, the last type is listening to a longer talk or conversation. Here, the students look for the gist, the main idea, and making inferences.

Differently, Nation and Newton (2009) propose two kinds of listening activity. The first is transactional listening (one - way - listening). In this listening activity, the speaker provides listeners with several information, such as material explanation from a teacher, TV news, political debate, etc. The next kind is interactional listening (two - way listening). This is a listening activity to maintain social relations. Greeting is one of examples of this kind.

Another view on listening comes from Anderson and Lynch in Nunan (2001). They point out that listening can be distinguished into reciprocal listening and non - reciprocal listening. Reciprocal listening refers to a listening task in which there is opportunity for the listener to interact with the speaker. Non - reciprocal listening refers to tasks such as listening to the radio or a formal lecture where the transfer of information is in one direction only - from the speaker to the listener.

Referring to the theories, several listening activities can be composed which can be seen in the following table.
Table 2: Listening Activities in EFL Classroom

\begin{tabular}{|l|l|l|}
\hline \multicolumn{1}{|c|}{$\begin{array}{c}\text { Types of } \\
\text { activity }\end{array}$} & $\begin{array}{c}\text { Spoken message } \\
\text { (listening } \\
\text { material) }\end{array}$ & \multicolumn{1}{|c|}{$\begin{array}{c}\text { Speaker - } \\
\text { hearer } \\
\text { interaction }\end{array}$} \\
\hline Intensive & Transactional & Non-reciprocal \\
\cline { 2 - 3 } & Interactional & Reciprocal \\
\hline Responsive & Transactional & Non-reciprocal \\
\cline { 2 - 3 } & Interactional & Non-reciprocal \\
\hline Selective & Transactional & Non-reciprocal \\
\hline Extensive & Transactional & rere \\
\hline
\end{tabular}

The table shows that there are four basic kinds of listening activities in which each type is with its own criteria. Intensive listening activity might be transactional and interactional but is non-reciprocal. Next, responsive listening might be transactional and interactional, as well as reciprocal and non-reciprocal. Both selective and extensive listening are transactional and non-reciprocal. Next, I will analyze how to get in touch with tasks in intensive, selective, and extensive listening by employing top-down processing.

\section{TOP - DOWN PROCESSING IN LISTENING FOR EFL STUDENTS}

\section{Intensive Listening}

The following script is an example of intensive listening which is transactional. The students are given a long stretch of language in order to have the perception of language component, word.

\section{Listening activity}

Direction: listen to this magazine article and fill in the blank spaces!

\section{FIRST IMPRESSION}

According to psychologists, people form first impressions based on how you ___ (1), then on how you ___ (2), and finally on what you say.

The way you look makes up (3) $\%$ of a first impression. This includes facial expressions, body language, and eye contact, as well as your clothes and general appearance. A friendly (4) seems to be the most important part of this.

The way you sound makes up (5) $\%$ of a first impression and includes how fast and slowly you (6). People listen to your tone of voice and decide if you sound (7) or unfriendly, interested or (8), and (9) or sad. What we say - the actual 
words - counts for only (10)

message.

People form first impressions within (11) seconds of meeting you. And first impressions don't change easily. If someone gets the wrong impression of you, it can take a long time to change his or her (12)

One problem is that in different parts of the world, the same behavior can give people a different impression. In some countries, if you look at the person (13), it shows you are friendly. In other countries, it can be rude, and it's more polite (14) away from the person. Standing close to someone and touching the person's arm is normal in some places, but in others it's better to keep your distance. The person may think you're being too (15) friendly!

Source: Let's Talk 2

On recognizing the title of the script First Impression, the students firstly refer to their background knowledge about the context of these words - meeting new people. They can imagine what usually happen in such situation, such as:

- How do people speak?

- How do people dress?

- What do people usually do?

- How do people make good or bad impression?

These questions guide the students to have the overall structure of the event - schema.

After that, the students bring the background knowledge they have in their mind to the text. They can glance over the text before the listening activity starts. To fill in the blank spaces, the students can infer words which best complete the spaces based on what they have already had in their mind.

For examples:

1. According to psychologists, people form first impressions based on how you look (1), then on how you sound (2), and finally on what you say.

The word look and sound are the words to complete the spaces. These words can be firstly inferred by the students based on their life experiences and cultural experiences about meeting new people for the first time.
2. The way you sound makes up $38 \%$ of a first impression and includes how fast and slowly you speak (6). People listen to your tone of voice and decide if you sound friendly (7) or unfriendly, interested or bored (8), and happy $(9)$ or sad. What we say - the actual words - counts for only

The words speak, friendly, bored, and happy can be found by referring to the students background knowledge of the topic and by referring to the previous stated information. The students, here, also involves their background knowledge of how words work in specific situation and how text is organized rhetorically.

Finally, to do top-down processing in this type of listening activity, the students need to involve their background knowledge of the topic, and their background knowledge of how words work in specific situation and of how text is organized rhetorically. Besides, the students need to have ability to refer to the previous stated information to infer what will come next. Those background knowledge and ability help students deal with the task.

\section{Selective Listening}

The following is an example of selective listening which is transactional. It is a task which provides students with a designated information in a context of longer stretches of spoken language to see whether the students can comprehend it or not.

\section{Listening activity}

Direction: Peter, Angie, and Jeff are talking about cities they used to live in. what do they say about the cities? Complete the chart!

\begin{tabular}{|l|l|l|l|}
\hline & Peter & Angie & Jeff \\
\hline Feeling on arrival & & & \\
\hline $\begin{array}{l}\text { Best ways to get } \\
\text { around }\end{array}$ & & & \\
\hline Best things to see & & & \\
\hline Things they miss & \multicolumn{3}{|c|}{ Source: Let's Talk 2 }
\end{tabular}

If the students have such task in listening activity, they should firstly glance over the table to have guide about what to find out. After that, they activate their background 
knowledge. It can be done through the following ways:

1) Since it is about the cities, the students have to recall their knowledge about the cities. For examples, they have buildings, cars, crowded people, places to visit, etc. in their mind. This is the knowledge about the context of a city.

2) The first point is about feeling on arrival. It requires the students to imagine what kinds of feeling a person has when they arrive in a city. For example, excited, nervous, relax, etc.

3) The second is about best ways to get around. The students can use the key word "the best ways to get around" to infer about how to go from one place to another, or about transportation. For example, by walking, by taxy, by ferry, by train, etc.

4) The third is about best things to see. The word "best things to see" gives the students clue about places. The students can infer places to visit in a city may be by referring to their life experience.

5) The last is about things they miss. The words "things they miss" also gives clue to the students. The students can infer things the speaker misses by looking for the key words such as love, like, unforgettable (at the end of the speakers' utterances) which are normally used to express like and dislike.

All of the background knowledge that the students have in their mind (point $1-5$ ) are employed in the task. By using the prior knowledge, the students can go directly to point they are looking for.

\section{Extensive Listening}

The following is an example of extensive listening which is transactional. It is listening to a longer talk or conversation. Here, the students look for the gist, the main idea, and making inferences.
Listening activity

\section{Recording script}

(Narrator)

Listen to an instructor talk to her class about Walt Whitman.

\section{(Woman)}

The topic of today's lecture is Walt Whitman, an American poet and author of the renowned collection of poems Leaves of Grass. This volume of poems is a celebration of America, full of pride in the United States and reverence for the goals of American democracy.

This lecture would probably be a part of which course?

a) Modern American Authors

b) United States history

c) American democracy

d) Nineteenth century American literature

Source: Longman Complete Course for the TOEFL Test: Preparation for the Computer and Paper Test

In this listening activity, the students are looking for the setting of the spoken text. The students firstly construct the schema of the text by finding out the key words. Based on the script, the students will hear the words lecture, Walt Whitman, poet, and poem. These words activate students' background knowledge about when and where the event happened. Finally, it will lead the students to the best choice $D$ (nineteenth century American literature).

\section{CONCLUSION}

Top-down processing in listening activities - intensive, selective, and extensive listening - works in several ways. In intensive listening, the students use the key words to infer the setting of the spoken text and activate their background knowledge of how text is organized rhetorically as well as how words work in specific situation. Then, in selective listening, besides using the key words, the students use their contextual knowledge of the topic to build the schema of the spoken text. Finally, in extensive listening, the students construct the schema of the text by finding out the key words as well as activate their background knowledge of 
how text is organized rhetorically, just like in intensive listening.

\section{References}

Anderson, Neil J. (2008). Lessons from good language learners. In Griffiths, Carol (Ed.), Metacognition and good language learners (pp. 99 109). Cambridge: Cambridge University Press

Brown, H. Douglas. (2004). Language assessment: Principal and classroom practice. San Fransisco: Pearson Education, Inc

David, Nunan. (2001). Designing task for communicative classroom. Cambridge: Cambridge University Press

Jones, Leo. (2008). Let's talk 2 ( $2^{\text {nd }}$ ed.). Cambridge: Cambridge University Press

Lingzhu, Ji. (2003). Listening activities for effective top-down processing. The Internet TESL Journal, IX,11, Retrieved on September 29, 2014, from

http://iteslj.org/Techniques/Lingzhu -Listening.html

Nation, I.S.P., \& Newton, Jonathan. (2009). Teaching ESL/EFL listening and speaking. Oxon : Routledge

Philips, Deborah. (2001). Longman complete course for the TOEFL test: Preparation for the computer and paper test. White Plains: Addison-Wesley Longman, Inc.

Richards, Jack C. (2008). Teaching listening and speaking: From theory to practice. Cambridge: Cambridge University Press

Rost, Michael. (2009). The Cambridge guide to teaching English to speakers of other languages. In Carter, Ronald., \& Nunan, David (Eds.), Listening (pp. 7 - 13). Cambridge : Cambridge University Press
Saricoban, Arif. (1999). The teaching of listening. The internet TESL Journal, $\quad V, 12$, Retrieved on January 26, 2014, from http://iteselj.org/Articles/SaricobanListening.html

Vandergrift, Larry. (2004). Listening to learn or listening to listen?. Annual Review of Applied Linguistics, 24, 3-25, Retrieved on September 29, 2014 , from http://www.unc.edu/courses/2007fal 1/germ/700/001/downloads/Vanderg rift.pdf.

White, Goodith. (2008). Lessons from good language learners. In Griffiths, Carol (Ed.), Listening and good language learners (pp. 208-217). Cambridge: Cambridge University Press 